received a Golden Bull for the following definition of the word 'container': "In relation to an investigational medicinal product, means the bottle, jar, box, packet or other receptacle which contains or is to contain it, not being a capsule, cachet or other article in which the product is or is to be administered, and where any such receptacle is or is to be contained in another receptacle, includes the former but does not include the latter receptacle."

Bamber says his medical colleagues don't object to the medical jargon among doctors. But as with specialized terminology in any profession, such language is often incomprehensible to outsiders, and when addressing a wider audience it is important to use plain English. Bamber adds that while the motion might not end the use of obscure language, "at least now we can say that it is the wish of the medical profession."

In response, the National Health Service issued a statement that it was "working to improve communication." - Mary Helen Spooner, London, England

DOI:10.1503/cmaj.091196

\title{
More news at cmaj.ca
}

Alzheimer disease: Canadian Institutes of Health Research President Dr. Alain Beaudet unveiled an international Alzheimer program as a prelude to developing a national dementia strategy. - Roger Collier, CMAJ

Cost recovery: Alberta is poised to become the first jurisdiction in the world to sue the convicted for the cost of treating injuries sustained in the commission of a crime. Christie MacLaren, Canmore, Alta.

Baby formula: Critics charge that a probiotic brand of infant formula may have potentially dangerous instructions. Roger Collier, CMAJ

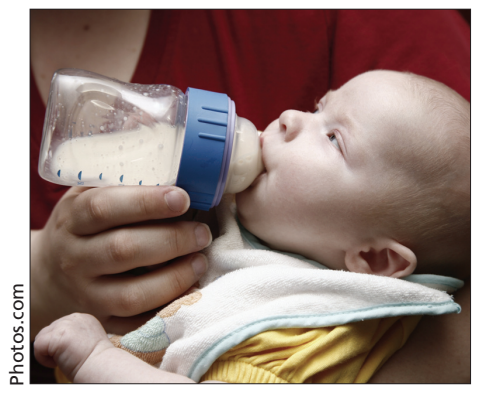

Nasty virus: Infectious disease specialists warn that a major novel $A(H 1 N 1)$ swine flu outbreak may occur in the fall because of the virus' capacity to reassort, possibly with H5N1. - Paul Webster, Toronto, Ont.

Generic drugs: Ontario projects that it will save $\$ 253$ million in 2008/09 with the Transparent Drug System for Patients Act. — Ann Silversides, CMAJ

Recession: The economic recession is projected to increase demand for some medical services, particularly mental health. - Roger Collier, CMAJ

Radiation passport: A University of Toronto radiation resident has developed a \$2.99 iPhone application to calculate cancer risks from medical exams such as computed tomography scans. - Christopher Mason, Ottawa, Ont.

Dispatch: A physician recalls disarming a young patient who entered a hospital with a live grenade. - Yasir Hameed, MD, Taiz, Yemen

Surveillance: The federal government has placed the Canadian Institutes of Health Research in charge of its Drug Safety and Effectiveness Network. Ann Silversides, CMAJ 